\title{
THE IMPACT OF THE MELD SCORE ON LIVER TRANSPLANT ALLOCATION AND RESULTS: AN INTEGRATIVE REVIEW
}

\author{
Impacto do escore MELD na alocação de fígado e nos resultados dos transplantes hepáticos: uma revisão integrativa
}

Ana Claudia Oliveira de MORAES, Priscilla Caroliny de OLIVEIRA, Olival Cirilo Lucena da FONSECA-NETO

From the Instituto Israelita Albert Einstein São Paulo, SP, Brazil.

HEADINGS - Liver transplantation. Survival analysis. End-stage liver disease
ABSTRACT - Introduction: Liver transplantation is intended to increase the survival of patients with chronic liver disease in terminal phase, as well as improved quality of life. Since the first transplant until today many changes have occurred in the organ allocation system. Objective: To review the literature on the Model for End-stage Liver Disease (MELD) and analyze its correlation with survival after liver transplantation. Method: An integrative literature review in Lilacs, SciELO, and Pubmed in October 2015, was realized. Were included eight studies related to the MELD score and its impact on liver transplant. Results: There was predominance of transplants in male between 45-55 y. The main indications were hepatitis $C$, hepatocellular carcinoma and alcoholic cirrhosis. The most important factors post-surgery were related to the MELD score, the recipient age, expanded donor criteria and hemotransfusion. Conclusion: The MELD system reduced the death rate in patients waiting for a liver transplant. However, this score by itself is not a good predictor of survival after liver transplantation.

\section{Correspondência:}

Ana Claudia Oliveira de Moraes,

Email: anamoraestx@gmail.com

Fonte de financiamento: não há Conflito de interesse: não há.

Recebido para publicação: Aceito para publicação:

DESCRITORES - Transplante de fígado Análise de sobrevida. Doença hepática em estágio terminal.
RESUMO - Introdução: O transplante de fígado tem como finalidade o aumento da sobrevida dos pacientes com doença hepática crônica em fase terminal, além de melhora na qualidade de vida. Desde o primeiro transplante até os dias atuais, muitas mudanças ocorreram no sistema de alocação de órgãos. Objetivo: Analisar o conhecimento produzido sobre o Model for End-stage Liver Disease (MELD) e a sua relação com a sobrevida no pós-transplante de fígado. Método: Realizou-se revisão integrativa nas bases de dados Lilacs, SciELO e Pubmed no mês de outubro de 2015. A amostra contou com oito estudos relacionando o escore MELD e o seu impacto no transplante de fígado. Resultados: Houve predomínio dos transplantes realizados em homens e faixa etária entre 45-55 anos. Como principais indicações tem-se hepatite $C$, hepatocarcinoma e cirrose por álcool. Os fatores que tiveram maior impacto no pós-operatório estão associados ao alto valor do MELD, idade do receptor, critérios expandidos do doador e hemotransfusão. Conclusão: O sistema MELD reduziu a mortalidade na fila de espera, mas isoladamente não é um bom preditor de sobrevivência no pós-transplante de fígado.

\section{INTRODUCTION}

T he aim of a liver transplant is to increase the survival of a patient with endstage liver disease and to improve quality of life $^{15}$. Since the first transplant, in 1963, many changes have significantly improved its success rate ${ }^{18}$.

The organ and tissue allocation system in Brazil has been through various phases that have led to better organization and greater credibility, reducing waiting lists and hence mortality'.

In 1997, the National Organ Transplant and Notification and Distribution Centers System was set up, which enabled the introduction of a Single Technical Register and a single waiting list ${ }^{1}$. At this time, the criterion used for conducting a transplant was time. However, it was noted that mortality on the waiting list was not related only to the waiting time $\mathrm{e}^{3,10}$.

Described for the first time in 2000, the aim of the MELD (Model for End-stage Liver Disease) score was to predict the three-month survival rate in patients who underwent a transjugular intrahepatic portosystemic anastomosis ${ }^{1,3,8}$. 
A 2001, study validated the MELD score as a measure of the probability of mortality within three months in transplant patients with end-stage chronic liver disease. In 2002, the United States started using this score as a criterion for liver allocation ${ }^{13,26}$.

A logarithmic calculation involving serum creatinine, bilirubin and International Normalized Ratio [0.957 x Log e (creatinine $\mathrm{mg} / \mathrm{dl})+0.378 \times$ Log e (bilirubin $\mathrm{mg} / \mathrm{dl}$ ) $+1.120 \times$ Log e (INR) $+0.643 \times 10$, rounded off to the nearest integer] is used to obtain the MELD score for recipients aged over 12 years. It is thus possible to obtain a good predictor of mortality, with a score close to 40 indicating minimal likelihood of survival within three months ${ }^{1,5,8}$.

The MELD as indicator of the severity of the clinical status of the recipient was introduced as a criterion in Brazil in 2006 by Decree 1160 . Since then, a policy has been adopted of using this procedure in more seriously ill patients, with the exception of emergencies and prioritized liver transplants, where allocation is conducted using other criteria, in accordance with current legislation 1,4,15,27.

This change brought about a reduction of 3,5\% in waiting list mortality, an increase of $10.2 \%$ in deceased donor transplants and a drop of $12 \%$ in patients scheduled for transplant ${ }^{3,15}$.

Examination of post-transplant survival showed that there may be a relation not defined by a high MELD score alone, but associated with the scarcity of organs, which led to the expansion of criteria for deceased donors beyond comorbidities.

The present study thus aims to examine the information produced on the MELD and its relation to survival and is guided by the following question: What impact does the MELD have on liver allocation and the results of liver transplants?

\section{METHODS}

A bibliographical survey was carried out in October 2015 using three indexed databases: Literatura Latino-Americana em Ciências da Saúde (Lilacs), the Scientific Eletronic Library Online (SciELO) and Pubmed. The articles were searched for using headings controlled by the Virtual Health Library by way of the Health Sciences Headings "liver transplant," "survival analysis" and "end-stage liver disease", and the MESHs (Medical Subject Headings) "liver transplantation," "survival analysis" and "end-stage liver disease".

The selection criteria for articles stipulated that they be available in full, in English, Spanish or Portuguese and published between 2010 and 2015 .

The initial search found 76 articles, 49 on Pubmed, 13 on Lilacs and 14 on SciELO. A reading of available titles and abstracts led to the exclusion of 57 articles, 40 from Pubmed, eight from Lilacs and nine from SciELO. Seven of the remaining articles were excluded for being duplicates, leaving 12 articles for analysis.

These remaining selected articles were evaluated using a methodologically rigorous tool adapted from the Critical Appraisal Skills Programme (CAPS) ${ }^{21}$ containing questions on the clarity of the objective, the adequacy of the methodology, theoretical and methodological procedures, sample selection, the relation between researcher and subject, ethical considerations, rigor and the foundation of data analysis, declaration of results, and the importance of the research.

Each item was worth one point and the score was the sum of points. Articles with a score of six to ten were classified as being of good methodological quality and low bias (level A) ${ }^{21}$ and were kept in the sample.

Using this tool, the 12 articles were selected and read in full. Eight answered the guiding question and were included in the final sample of the present review: four were from Pubmed, two from Lilacs and two from SciELO (Figure 1).

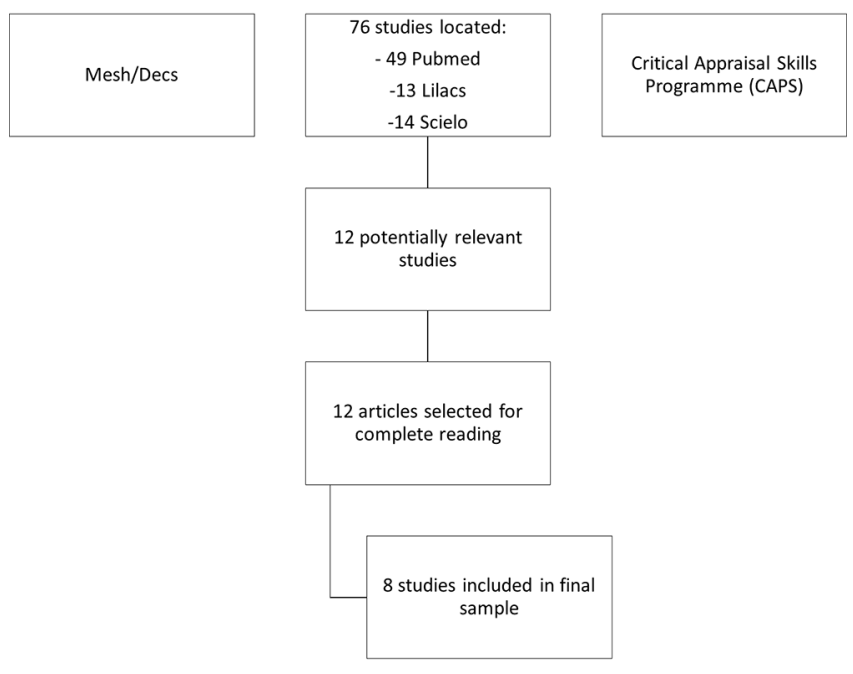

FIGURE 1 - Flowchart of article selection process

\section{RESULTS}

Most articles described retrospective cohort-type studies. Figure 2 shows the selected articles and publications.

Most of the liver transplant patients in the articles were male and middle-aged (45-55 years). Most of the studies compared the pre- and post-MELD eras and the inclusion criteria were age $\geq 18$ years, deceased donor transplants, and, in two studies, dual liver-kidney transplant.

Cases with incomplete medical records and those involving re-transplants, inter-vivo transplants, acute liver failure as an indication, children, multiple organs, and "split-liver" or "domino" operations were generally excluded. Only one study did not include patients with a special MELD score, such as those with hepatocarcinoma ${ }^{24}$ and one other ${ }^{16}$ examined only cases involving patients aged over 50 .

The main indications were viral hepatitis $2,11,17,20,23$ (especially hepatitis C) and alcoholic cirrhotic hepatocellular carcinoma. Patients with hepatocellular carcinoma were selected using the Milan criterion ${ }^{5}$, which classifies cirrhotic patients with a single nodule of up to $5.0 \mathrm{~cm}$ in diameter or up to three of up to $3.0 \mathrm{~cm}$ in diameter according to the absence of neoplastic thrombosis of the portal system and the absence of extra-hepatic lesions.

The use of the MELD score as a criterion for liver allocation was found to increase the number of transplantations in cases of hepatocellular carcinoma up to eight-fold ${ }^{23}$.

As expected, a reduction in waiting-list mortality was confirmed by all studies $2,6,11,16,17,20,23,24$. However, analysis of postoperative survival revealed that this score is not a good predictor in isolation. This conclusion varied according to the length of time after the transplant surgery but the results were similar for the postoperative period as a whole.

In cases of dual (liver-kidney) transplants, the short-term survival rate was similar but, in the long term, a single (liver) transplant had a better outcome ${ }^{20}$. Hepatocellular carcinoma did not correlate with a worse survival rate and cases that were not in an advanced stage were found to be associated with lower postoperative morbidity and mortality ${ }^{11,17}$. One study ${ }^{16}$ found hepatocellular carcinoma to be a risk factor for higher mortality within five years.

Factors that had a postoperative impact and worse survival rates included: delay between supply and demand, which may cause the MELD score to increase while waiting for the transplant, producing a more severe condition at the time of the surgery and hence a greater likelihood of complications; age over 60 years; pre-transplant dialysis; the use of broader criteria to select donors; and transfusion of blood products. 


\begin{tabular}{|c|c|c|c|}
\hline Title & Aim & Periodical/Year & Study characteristics \\
\hline $\begin{array}{l}\text { Adoption of the MELD score has } \\
\text { increased the number of liver } \\
\text { transplants }{ }^{20}\end{array}$ & $\begin{array}{l}\text { The aim of this study was to assess the incidence } \\
\text { and results of liver transplants carried out at a } \\
\text { single center in South America before and after the } \\
\text { adoption of the MELD score. }\end{array}$ & $\begin{array}{l}\text { ABCD Arq Bras Cir } \\
\text { Dig/2014 }\end{array}$ & $\begin{array}{c}\text { Location: São Paulo- SP } \\
\text { Study Type: Retrospective } \\
\text { cohort } \\
\text { Sample: } 623 \text { transplants }\end{array}$ \\
\hline $\begin{array}{l}\text { Use of the MELD score to predict post } \\
\text { liver transplant survival }{ }^{2}\end{array}$ & $\begin{array}{c}\text { The aim of the study was to evaluate the accuracy } \\
\text { of the pre-operative MELD score for prediction of } \\
\text { post-LT survival and investigate factors predicting } \\
\text { medium-term survival ( } 24 \text { months). }\end{array}$ & $\begin{array}{l}\text { Rev. Col. Bras. } \\
\text { Cir./2012 }\end{array}$ & $\begin{array}{l}\text { Location: Recife- PE } \\
\text { Study Type: Cross-sectional } \\
\text { cohort } \\
\text { Sample: } 208 \text { transplants }\end{array}$ \\
\hline $\begin{array}{c}\text { The MELD system and waiting-list } \\
\text { mortality for liver transplantation in } \\
\text { developing countries: lessons learnt in } \\
\text { São Paulo }\end{array}$ & $\begin{array}{c}\text { To assess the impact of the MELD system on } \\
\text { waiting-list mortality in the State of São Paulo, } \\
\text { Brazil. }\end{array}$ & Einstein/2012 & $\begin{array}{l}\text { Location: São Paulo- SP } \\
\text { Study Type: Retrospective } \\
\text { Cohort } \\
\text { Sample: } 1911 \text { transplants }\end{array}$ \\
\hline $\begin{array}{l}\text { The impacto of the Model for End- } \\
\text { Stage Liver Disease (MELD) on liver } \\
\text { transplantation in on center in Brazil }{ }^{11}\end{array}$ & $\begin{array}{l}\text { The study aimed to compare the results of liver } \\
\text { transplantation before and after the introduction of } \\
\text { MELD at a center in Brazil. }\end{array}$ & $\begin{array}{c}\text { Arquivo } \\
\text { Gastroenterol/2010 }\end{array}$ & $\begin{array}{l}\text { Location: Curitiba- PR } \\
\text { Study Type: Retrospective } \\
\text { cohort } \\
\text { Sample: } 111 \text { transplants }\end{array}$ \\
\hline $\begin{array}{l}\text { Analysis of the survival of cirrhotic } \\
\text { patients enlisted for liver transplantation } \\
\text { in the pre - and post- MELD era in } \\
\text { Southern Brazil }{ }^{17}\end{array}$ & $\begin{array}{l}\text { The study aimed to compare the MELD to the } \\
\text { transplant policy based on waiting time used } \\
\text { previously. }\end{array}$ & $\begin{array}{c}\text { Arq } \\
\text { Gastroenterol/2014 }\end{array}$ & $\begin{array}{l}\text { Location: Rio Grande do } \\
\text { Sul- RS } \\
\text { Study Type: Retrospective } \\
\text { cohort } \\
\text { Sample: } 346 \text { transplants }\end{array}$ \\
\hline $\begin{array}{l}\text { Combined effects of recipient age and } \\
\text { Model for Enf-Stage Liver Disease score } \\
\text { on liver transplantation outcomes }{ }^{24}\end{array}$ & $\begin{array}{l}\text { The study aimed to evaluate the liver } \\
\text { transplantation outcomes according to a } \\
\text { combination of age and MELD score at the time of } \\
\text { the transplant operation. }\end{array}$ & Transplantation/2014 & $\begin{array}{c}\text { Location: United States } \\
\text { Study Type: Retrospective } \\
\text { cohort } \\
\text { Sample: } 15677 \text { transplants }\end{array}$ \\
\hline $\begin{array}{c}\text { Improved waiting-list outcomes in } \\
\text { Argentina after the adoption of a Model } \\
\text { for End-Stage Liver Disease - Based liver } \\
\text { allocation policy }\end{array}$ & $\begin{array}{l}\text { The study aimed to investigate the applicability and } \\
\text { outcomes of liver transplantation in Argentina in } \\
\text { the past decaded before and after adoption of an } \\
\text { allocation policy based on the MELD. }\end{array}$ & $\begin{array}{l}\text { Liver } \\
\text { transplantation/2013 }\end{array}$ & $\begin{array}{c}\text { Location: Argentina } \\
\text { Study Type: Retrospective } \\
\text { cohort } \\
\text { Sample: } 3272 \text { transplants }\end{array}$ \\
\hline $\begin{array}{l}\text { Outcomes among older adult liver } \\
\text { transplantation recipients in the Model of } \\
\text { End-Stage Liver Disease (MELD) era }{ }^{16}\end{array}$ & $\begin{array}{l}\text { The study aimed to describe the outcomes for } \\
\text { older adults of liver transplantation in the MELD } \\
\text { era. }\end{array}$ & Ann Transplant/2014 & $\begin{array}{c}\text { Location: United States } \\
\text { Study Type: Retrospective } \\
\text { cohort } \\
\text { Sample: } 35686 \text { transplants }\end{array}$ \\
\hline
\end{tabular}

FIGURE 2 - Studies of the impact of the MELD on liver allocation and outcomes of liver transplantation included in the integrative review

DISCUSSION

In terms of age and the predominance of male transplant patients, the findings of the various studies were similar $3,9,14,15$. Waiting-list mortality and exclusion for reason of worsening of the underlying condition are more common among women, possibly because of lower creatinine levels. This shows that women are at a disadvantage under a MELDbased allocation system ${ }^{15}$.

Hepatitis $\mathrm{C}$ is the main indication for liver transplantation and $\mathrm{HCV}$ recidivism, which is considered the most common cause of graft loss, occurs in $90 \%$ of patients in the first year after surgery 22 .

The Ministry of Health defines cases of hepatitis C confirmed by positive anti-HCV and HCV-RNA as detectable. The detection rate is high and more common in patients aged between 30 and 59 years and has been reported by Sharpton et al. ${ }^{24}$ as the main indication for transplantation in young patients ${ }^{14}$.

The MELD era has seen an increase in transplantation for hepatocellular carcinoma and fewer patients excluded from the waiting list ${ }^{15,17,23}$. In many of these cases, liver functioning is fairly well preserved and this leads to a lower MELD score, a longer waiting time and worsening of the patient's condition. Additional points are thus added to the score to compensate for the higher risk of being without criteria for liver transplantation for reason of a tumor or metastasis, benefiting these patients without disadvantaging other cases. It is worth noting that the waiting time for transplantation has shortened considerably in MELD era, leading to higher survival rates $1,5,15,23,28$

The three-month increase in waiting-list survival was confirmed by the present review but, after surgery, the best outcomes are associated with a low MELD score. In Machado ${ }^{15}$, various studies attempted to relate this score to the post-transplant period and establish a cut-off point to guide the decision not to perform transplantation, despite the worst outcomes occurring with the higher MELD scores. But this was not possible?

Cases of dual (liver-kidney) transplants increased during the MELD era and there was not much difference in short-term survival rate between this procedure and liver transplant alone. Veras et al. ${ }^{25}$ came up with a similar finding but also noted a lower survival rate in the $3^{\text {rd }}$ and $5^{\text {th }}$ years after a dual transplant.

Furthermore, cases of pre-operative kidney dysfunction are more likely to result in the need for dialysis after transplantation, primary liver graft dysfunction and death. This suggests that a dual transplant may benefit these recipients ${ }^{19,25}$.

Although the MELD score is not directly related to transplantation outcomes, some features are better correlated with the postoperative scenario. Advanced age may lead to early loss of the graft, especially when combined with a high MELD score, with almost half of these transplant patients with a MELD $\geq 28$ dying in the first year ${ }^{24}$. This may also be due to comorbidities associated with age.

Blood transfusion is also linked to reduced survival after transplantation ${ }^{2,11}$, with an association between multiple transfusions and complications seen as a predictor of survival ${ }^{3}$.

This may be related to immunomodulation related the transfusion of blood products and also by the storage process resulting in an increase in hospital infections, acute lung damage and the development of autoimmune diseases in the long term. The need for blood transfusion may also be related to the severity of the condition of the patient at the time of the transplant surgery, in which cases a lower survival rate was already expected ${ }^{2,19}$.

Another important issue is the scarcity of organs, which leads to the broadening of criteria used to select donors around the world with good results. However, some factors relating to the donor, such as age, race, cardiac arrest, stroke, 
cold ischemia time and split liver are related to early graft failure, especially in the case of the age of the donor ${ }^{2,12,16}$.

The factors that have the greatest impact on liver transplantation survival are not directly linked to the severity score used in Brazil since 2006. Furthermore, the intrinsic limitations of the MELD and those associated with the clinical condition of the patient have led to the incorporation of new variables to improve its predictive capacity ${ }^{15}$.

\section{CONCLUSION}

The change to the MELD system of allocation has increased the number of transplants and led to lower waiting-list mortality. However, it has not had a significant impact on post-transplant outcomes or survival. A combination of the MELD score and other preoperative factors may provide a better indication of the likelihood of complications and allow for better assessment of the risks of the operation. As yet there is no score that better predicts the outcomes of surgery but it is clear that MELD alone is not a good predictor of survival subsequent to liver transplant surgery.

\section{REFERENCES}

1. Andraus W, Haddad L, Rocha-Santos V, D'Albuquerque LAC. Análise dos sistemas de alocação de órgãos para transplantes do aparelho digestivo no Brasil. Medicina (Ribeirão Preto) 2013; 46 (3): 237-42.

2. Batista TP, Sabat BD, Melo PSV, Miranda LEC, Fonseca-Neto OCL, Amorim AG, Lacerda CM. Emprego do escore MELD para a predição da sobrevivência pós-transplante hepático. Rev. Col. Bras. Cir. 2012; 39(2): 105-111.

3. Boin IFSF, Leonardi MI, Udo EY, Sevá-Pereira T, Stucchi RSB, Leonardi LS. Aplicação do escore MELD em pacientes submetidos a transplante de fígado: análise retrospectiva da sobrevida e dos fatores preditivos a curto e longo prazo. Arq Gastroenterol 2008 out. / dez; 45 (4)

4. Brasil. Portaria no 1160, de 29 de maio de 2006. Disponível em: <http:// www.saude.sp.gov.br/resources/ses/legislacao/2006/junho/informeeletronico-de-legislacao-em-saude-n122-29.06.06/legislacaofederal/u_ptms-gm-1160-rep_290506.pdf> Acesso em: 13 de out. de 2015.

5. Brasil. Portaria $n^{\circ} 2600$, de 21 de outubro de 2009. Disponível em: <http:// bvsms.saude.gov.br/bvs/saudelegis/gm/2009/prt2600_21_10_2009. html> Acesso em: 07 de out. de 2015

6. Cejas NG, Villamil FG, Lendoke JC, Tagliafichi V, Lopez A, Krogh DH, Soratti CA, Bisigniano L. Improved waiting-list outcomes in Argentina after the adoption of a Molde for End-Stage Liver Disease - Based liver allocation policy. LIVER TRANSPLANTATON 2013 July; 19: 711-720.

7.ChaibE, FigueiraERR, Brunheroto A, GattiAP, FernandesDV, D'Albuquerque LAC. A seleção de pacientes utilizando-se o critério meld melhora a sobrevida a curto prazo dos pacientes submetidos ao transplante de fígado? ABCD Arq Bras Cir Dig 2013; 26(4): 324-327.

8. David Al, Coelho MPV, Paes AT, Leite AK, Bianca DG, Almeida MD, Meira SP, Rezende MB, Afonso RC, Ferraz-Neto BH. Comparação da evolução do transplante hepático em receptores com MELD alto e baixo. Einstein 2012; 10(1): 57-61.

9 Ferreira LL, Arroyo Júnior PC, Silva RCMA, Lamari NM, Cavenaghi OM. Perfil de pacientes em pré-operatório para transplante de fígado em hospital de ensino. Health Sci Inst. 2013; 31(3): 84-7.

10. Freeman RB Jr, Edwards E. United Network for Organ Sharing Liver and Intestine Committee. Liver transplant waiting time does not correlate with waiting list mortality: implications for liver allocation policy. Liver Transplant. 2000; 6: 543-52.
11. Freitas ACT, Itikawa WM, Kurogi AS, Stadnik LG, Parolin MB, Coelho JCU. The impact of the model for end-stage liver disease (MELD) on liver transplantation in one center in Brazil. Arq Gastroenterol 2010 jul./set.; 47(3).

12. Halldorson JB. Bakthavatsalam R. Fix O, Reyes JD, Perkins JD. D-MELD, a simple predictor of post liver transplant mortality for optimization of donor/recipient matching. American Journal of Transplantation 2009; 9: 318-326.

13. KamathPS, Wiesner RH, MalinchocM, KremersW, TherneauTM, Kosberg CL, D'Amico G, Dickson ER, Kim WR. Predict survival in patients with end-stage liver disease. Hepatology 2001; 33(2).

14. Lombardi AC, Mente ED, Sankarankutty AK, Souza FF, Teixeira AC, Cagnolati D, Souza MEJ, Castro e Silva Jr O. Analysis of 83 consecutive liver transplants performed at a tertiary care reference hospital in the interior of the state of São Paulo. Acta Cirúrgica Brasileira 2011; 26(6).

15. Machado AGS. Impacto da implantação do escore MELD na alocação de fígado e nos resultados dos transplantes hepáticos: a experiência de um centro brasileiro. [Dissertação]. [Porto Alegre]: Universidade Federal de Ciências da Saúde de Porto Alegre; 2011. 83 p.

16. Malinis MF, Chen S, Allore HG, Quagliarello VJ. Outcomes among older adult liver transplantation recipientes in the Model of End Stage Liver Disease (MELD) Era. Ann Transplant 2014; 19: 478-487.

17. Mattos AZ, Mattos AA, Sacco FKF, Hoppe L, Oliveira DMS. Analysis of the survival of cirrhotic patient enlisted for liver transplantation in the pre-and post - MELD era in Southern Brazil. Arq Gastroenterol 2014 jan./mar.; 51(1).

18. Meirelles Júnior RF, Salvalaggio $P$, Rezende MB, Evangelista AS, Guardia BD, Matielo CEL, Neves DB, Pandullo FL, Felga GEG, Alves JAS, Curvelo LA, Diaz LGG, Rusi MB, Viveiros MM, Almeida MD, Pedroso PT, Rocco RA Meira FilhoSP. Transplante de fígado: história, resultados e perspectivas. Einstein 2015; 13(1):149-52.

19. Morais BS, Sanches MD, Lima AS, Ribeiro DD, Ferrari TCA, Duarte MMF, Cançado GHGM. Associação entre uso de hemocomponentes e mortalidade em cinco anos após transplante hepático. Revista Brasileira de Anestesiologia 2011 Maio-Junho; 61(3): 286-292.

20. Nacif LS, Andraus W, Martino RB, Santos VR, Pinheiro RS, Haddad LBP, D'Albuquerque LC. Adoção do escore MELD aumentou o número de transplantes de fígado. ABCD Arq Bras Cir Dig 2014; 27 (3):201-203.

21.Public Health ResourceUnit, TheUniversity of Kent, CriticalAppraisal of the Journal Literature.Critical AppraisalSkills Programme(CASP)-Evaluation tool for quantitative studies. England: Public Health Resource Unit; 2006.

22. Reis MM, Resende PN, Vieira GA, Gomide GPM, Molina RJ, Cabral SCO. Cirrose por HCV genótipo $1^{\circ}$, tratada com 7 semanas de interferon peguilado/ribavirina, transplantada por hepatocarcinoma em RVS. GED gastroenterol. Endosc. Dig. 2015; 34(2): 72-75.

23. Salvalaggio P, Afonso RC, Pereira LA, Ferraz-Neto BH. O sistema MELD e a mortalidade em lista de espera para transplante de fígado em países em desenvolvimento: lições aprendidas em São Paulo. Einstein 2012 10(3): 278-85.

24. SharptonSR. FengS, Hameed B, Yao F, LaiJC.Combined effects of recipient age and Model for End-Stage Liver Disease score on liver transplantation outcomes. Transplantation 2014 september; 98(5): 557-562.

25. Veras FJO, Coelho GR, Feitosa-Neto BA, Cerqueira JBG, Garcia RCFG, Garcia JHP. Transplante combinado fígado-rim: experiência de um hospital universitário brasileiro. ABCD Arq Bras CirDig 2014;27(1):53-55.

26. Wiesner R, Edwards E, Freeman R, Harper A, Kim R, Kamath P, Kremers W, Lake J, Howard T, Merion RM, Wolfe RA, Krom R. Model for end-stage liver disease (MELD) and allocation of donor livers. Gastroenterology 2003 Jan; 124(1):91-96.

27. Ribeiro-JR MAF, Medrado MB, Rosa OM, Silva AJD, Fontana MP Cruvinel-Neto J, Fonseca AZ. Liver transplantation after severe hepatic trauma: current indications and results. ABCD Arq Bras Cir Dig 2015 Nov./Dec.; 28(4): 286-9.

28. FreitasAC, Shiguihara RS,MonteiroRT, PazetoTL, CoelhoJCU.Comparative study on liver transplantation with and withouthepatocellularcarcinoma with cirrhosis: Analysis of MELD, waiting time and survival. ABCD Arq Bras Cir Dig 2016 Mar; 29 (1): 21-25. 